\title{
Correction to: Characterization of the Gh4CL gene family reveals a role of Gh4CL7 in drought tolerance
}

\author{
Shi-Chao Sun ${ }^{1}$, Xian-Peng Xiong ${ }^{1}$, Xiao-Li Zhang ${ }^{1}$, Hong-Jie Feng ${ }^{2}$, Qian-Hao Zhu ${ }^{3}$, Jie Sun ${ }^{1 *}$ and Yan-Jun Li ${ }^{\text {1* }}$
}

\author{
Correction to: BMC Plant Biol (2020) 20:125 \\ https://doi.org/10.1186/s12870-020-2329-2
}

In the original publication [1] there was an incorrect funding number. The incorrect and correct funding number are published in this correction article. The original article has been updated.

\section{Incorrect funding}

- This work was supported by the National Natural Science Foundation of China (Grant No: 31906438 , 31360347), the National Key Research and Development Program of China (Grant No: 2016YFD0100200) and the Breeding Program of Shihezi University (Grant No:YZZX201601). The funding bodies had no role in the design of the study and collection, analysis, and interpretation of data and in writing the manuscript.

\section{Correct funding}

- This work was supported by the National Natural Science Foundation of China (Grant No: 31960438, 31360347), the National Key Research and Development Program of China (Grant No: 2016YFD0100200) and the Breeding Program of Shihezi University (Grant No:YZZX201601). The funding bodies had no role in the design of the study and collection, analysis, and interpretation of data and in writing the manuscript.

\begin{abstract}
Author details
${ }^{1}$ Key Laboratory of Oasis Eco-agriculture, College of Agriculture, Shihezi University, Shihezi 832000, Xinjiang, China. ${ }^{2}$ Key Laboratory of Cotton Biology, Institute of Cotton Research, Chinese Academy of Agricultural Sciences, Anyang 455000, Henan, China. ${ }^{3} \mathrm{CSIRO}$ Agriculture and Food, GPO Box 1700, Canberra 2601, Australia.
\end{abstract}

Published online: 28 January 2021

\section{Reference}

1. Sun $\mathrm{SC}$, Xiong XP, Zhang XL, et al. Characterization of the $G$ h $4 C L$ gene family reveals a role of Gh4CL7 in drought tolerance. BMC Plant Biol. 2020; 20:125 https://doi.org/10.1186/s12870-020-2329-2.

The original article can be found online at https://doi.org/10.1186/s12870020-2329-2.

*Correspondence: sunjie@shzu.edu.cn; lyj20022002@sina.com.cn

'Key Laboratory of Oasis Eco-agriculture, College of Agriculture, Shihezi University, Shihezi 832000, Xinjiang, China

Full list of author information is available at the end of the article

(C) The Author(s). 2021 Open Access This article is licensed under a Creative Commons Attribution 4.0 International License, which permits use, sharing, adaptation, distribution and reproduction in any medium or format, as long as you give appropriate credit to the original author(s) and the source, provide a link to the Creative Commons licence, and indicate if changes were made. The images or other third party material in this article are included in the article's Creative Commons. licence, unless indicated otherwise in a credit line to the material. If material is not included in the article's Creative Commons licence and your intended use is not permitted by statutory regulation or exceeds the permitted use, you will need to obtain permission directly from the copyright holder. To view a copy of this licence, visit http://creativecommons.org/licenses/by/4.0/ The Creative Commons Public Domain Dedication waiver (http://creativecommons.org/publicdomain/zero/1.0/) applies to the data made available in this article, unless otherwise stated in a credit line to the data. 